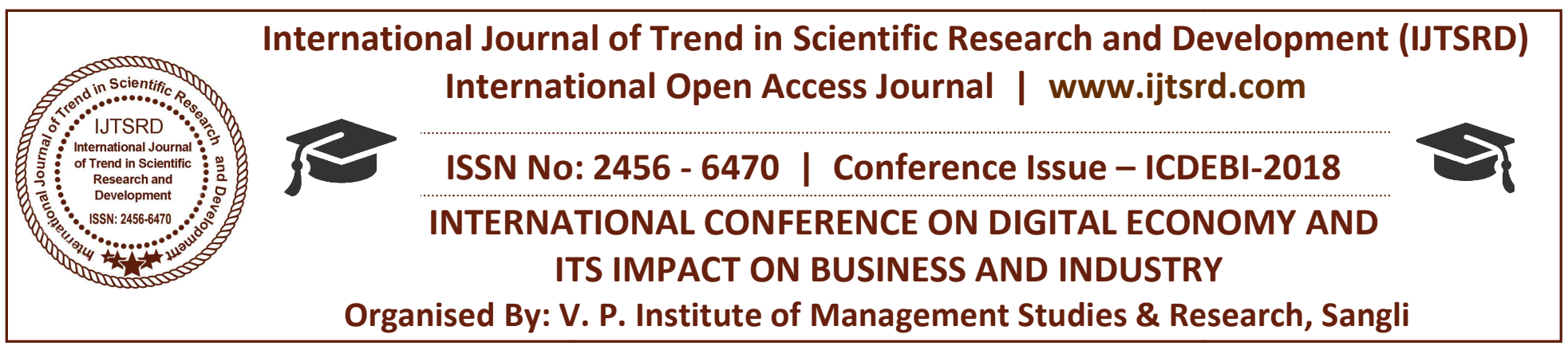

\title{
Importance of Banks in Cashless Transactions under Digitalization System
}

\author{
Mr. S S Halemani \\ Assistance Professor in commerce, Government First Grade College Hunnur, \\ Jamkhandi, Bagalakot, Karnataka, India
}

\section{ABSTRACT}

Banking sector plays an important role in economic development of India, huge changes in digitalization system and new techniques in technology have changed the entire banking system. Basically Indians are slow in nature to adjust the modern techniques from the traditional methods. Union government of India forced Indian citizens to switch to the cashless transaction by taking bold decisions of demonetization. After note ban decision people of the nation depressed the system of note ban, but due to the digitalization system faster changes has taken place in the distribution and circulation of rupees notes. Effect of digitalization, net banking, mobile banking, debit card, credit card, e-services, and epayments number of changes has been taken in banks. Sweden is the first nation to adopt cashless transaction in the world. $10-15 \%$ of Indian population and up to $40 \%$ of Brezile and Chaina's population has adopted cashless transaction. But recently in India more than $30 \%$ of Indian citizens are using cashless transaction. A common man can transact his banking business by using electronic apps easily. Even in rural area's banks are also started to adopted digital system to provide faster service to their customer. By using digitalization services profits can be easily access through good services. There are number of problems may disturbed after by using the system but these can be manageable if we aware about the threats of technology. Today's cashless transaction shows the remarkable changes have been took place in the mind of costumers. In present scenario, Indian economic sector have been identified faster progress in the world even in suffering serious diseases like black money, terrorism, illegal propriety etc, and also hope that these can be manageable by the legal cell the country.

\section{A. Introduction}

Modern banking system plays an important role in boosting the Indian Economy in the world. After the demonetization there is real struggle against Black Money, Corruption, Crimes and terrerisium. In such a situation, Indian Banks are playing a role model in the field of digitalization to adopt cashless transaction to all types of customers and facing the problems of security and cyber crimes. Banks are started to provide services and products through electronic devices with the help of Internet. The role of RBI is amazing to make plans and policies in the right time to help all banks to collect banned currency notes and issue new Notes. It is time to give grate credit to all Banks' employees and Management, those who are dedicated their time and energy at the time of demonetization decision by the government. Today cashless transaction shows the remarkable changes have been taken place in the minds of customers. Recently new apps like BHIM, PhonePe, Google Pay etc, are providing best service to customers.

\section{B. Review Of Literature}

1. Manpreet Kaur (2017) Explained in his paper the effect of demonetization on Indian Economy and how to people should adjust the cashless payment system. He said the cashless system has provides fringe benefits our society like time management. Low cost of transaction and paper less business.

2. Lokesh (2017) He explained in his paper about demonetization and cashless transaction will short 
term negative effect on economy but long term benefits to all in the future. Banks are busy to proved quicker service to the society.

3. Nitin and Sharmila (2016) explained the system of cashless business after the demonetization and started to circulate the cash systematically. They desired that all short term problems can be solved by using digitalization system in the banks.

4. Vijay and Shiva (2016) It is the real test of all banks to adjust the system of demonetization and provide quick service to the society by facing operational and security problems.

\section{Objective Of The Study}

1. To know the services available in the banks relating to cashless transactions.

2. To analyses the favorable and unfavorable outcomes of cashless transactions.

\section{Methodology Of The Study}

The present paper is prepared by using secondary data available in the news papers, Magazines, Journals, Books and government web site. The study tries to bring out the importance banks in cashless transaction under digitalization system.

\section{E. Importance Of Banks In Cashless Transaction Under Digitalization System}

Sweedon is the first nation to adopt cashless transaction in the world. In India $10-15 \%$ of population and up to $40 \%$ of Brezile and Chaina's population has adopted cashless transaction, and recently in India, more than $30 \%$ of the population using cashless transaction. There was revolution in paper transaction converted in to digital transaction by using credit card, debit cards, EFT or online business to maintain purity in the financial matter. All kinds of business like buying and selling of things, Vegetables, Business centre, taxi centre, Petroleum centre and reduce the huge cost on printing notes. As per the information available in the Feb 2017 Yojana Magazine relating to RBI information the following table shows the cash transaction existed during the year 2015-16 in the world.

\section{Chart of cash circulation (\% in GDP)}

\begin{tabular}{|l|l|l|l|l|l|}
\hline Nation & $\mathbf{2 0 1 1}$ & $\mathbf{2 0 1 2}$ & $\mathbf{2 0 1 3}$ & $\mathbf{2 0 1 4}$ & $\mathbf{2 0 1 5}$ \\
\hline India & 12.1 & 11.9 & 11.5 & 11.6 & 12.3 \\
\hline Brazil & 3.8 & 4.00 & 3.9 & 4.00 & 3.8 \\
\hline $\begin{array}{l}\text { South } \\
\text { Korea }\end{array}$ & 3.8 & 4.00 & 4.2 & 5.00 & 5.8 \\
\hline Sweden & 2.8 & 2.5 & 1.7 & 2.00 & 1.7 \\
\hline U.K & 3.8 & 3.5 & 3.5 & 3.8 & 3.6 \\
\hline America & 6.2 & 6.9 & 6.9 & 6.6 & 7.4 \\
\hline
\end{tabular}

The above table shows that India has same percentage of use of currency note since form 2011 to 2015, but Sweden has lowest currency notes always since from 2011-2015. Compare with all contrary in the above table India has highest currency notes using country.

As per the statistic reports relating to use of cards holders for each person during the year 2015-16 shows the below:

India

Sweedan

South korea

Brazil

cheena

- $50 \%$ of total population

-2.5 each person

- 5.5 each person

- 4.1 each person

-4.00 each person

From the above information it is clearly show that all four countries except India is using minimum electronic cards.

Objectives of cashless transaction:

1. To avoid use of papers notes maximum to reduce the cost of printing of notes.

2. (20 To reduce the laborious work to pay and collect the money in the banks.

3. To create faith on money transaction by using electronic devices.

4. To provide best service to all kind of customer without disturbing their will power.

5. To strengthen our economy by making huge business through digitalization media and boost the GDP.

6. To maintain solvency position not only in national level but also international level.

7. To provide proper knowledge to common man of the nation to addict the new system to make more business.

8. To remove the black money in the gross level.

9. To know all feature of banks all business by using digital device in any place, at any time.

In the present scenario all categories of Banks are adopted digitalization technology by reducing laborious and cost of paper to print the Notes and use through paper work. The following are the facilities available in all banks to provide cashless transaction to the society .Money can transfer and deposited one account to another account easily.
a. Internet Banking
b. On Line Banking
c. Automatic Teller Machine
d. Telephone Banking 
e. Banking Automated Clearing System

f. Clearing House Automated Clearing System

g. Electronic Data Interchange

h. Electronic Clearing Service

i. Smart Cards

j. $\quad$ Debit And Credit Cards

k. New Apps Like Bhim, Phonepe, Google Pay Etc.

\section{Advantages of Cashless Transactions}

Rapid changes in digital area number of advantages are available to all the people are as under:

1. Easy to payment: it creates awareness among the people to pay any king of bill through electronic devices by using their secret code to pay easily their bill leads to reduce the labor and cost.

2. Riskless business and no tension: by using proper code and password in right direction to fill all the information neatly. No doubt no risk to anybody and same time avoids the security problems easily.

3. Reduce the cost of printing the notes: the problem of security and cost can be reducing by using cashless transaction. The cost of printing notes RS 2700 Cores in the year 2015 it is shows that printing cost is very high.

4. Reduce the crimes: the time has to be come at the door level to reduce the crime rates by using digital system in cashless business can reduce the misappropriation of using or managing the financial transaction.

5. Reduce the Demand and collection: cashless transaction reduce the demand of notes and keeping huge amount in the bank. The circulation of the money can be done only through cashless business transferring funds from one account to another account with lesser cost

\section{Disadvantages}

1. Difficult to adopt: The digitalization has needed knowledge of use of new banking facilities and there is the problem of literate the people.

2. Security Problems: Cashless transactions are facing security problems due to the virus problems.

3. More work and stress: Due to the shortage of employees, employees are put under heavy work to manage the customers and transactions.

\section{F. Conclusion}

It is time to show the caliber of digitalization system to boost the economy of the nation in the international level. Effect of demonetization disturbs the mind of the people in shorter period but it provides positive energy to the society to adjust the new system banking transactions. Governments are trying to provide necessary plans and police time to time than it is possible to build strong economy for smooth running the banking activities.

\section{References}

1. Yojana Montly Magzine (Kannada) Feb 2017.

2. Demonetisation and its effects on banking sector by Dr M. P rabhu ISOR, Jounal of Business and Management April 2017.

3. - Lokesh Uke (2017) Demonetization and its effects in India International Journal of Economics and Management Feb 2017. 